\title{
Nursery performance of potentially promising rootstocks for citriculture in the south of Brazil
}

\section{Léo Omar Duarte Marques $^{*}$ (i) Paulo Mello-Farias ${ }^{1}$ (i) Roberto Pedroso de Oliveira ${ }^{2}$ (i) Maximiliano Dini ${ }^{1,3}$ (i) Rodrigo Fernandes dos Santos ${ }^{1}$ (i) Marcelo Barbosa Malgarim $^{1}$ (i) Walter dos Santos Soares Filho ${ }^{4}$}

${ }^{1}$ Programa de Pós-graduação em Agronomia, Universidade Federal de Pelotas (UFPel), 96160-000, Capão do Leão, RS, Brasil. E-mail: leodmq@hotmail.com."Corresponding author.

${ }^{2}$ Empresa Brasileira de Pesquisa Agropecuária (Embrapa Clima Temperado), Pelotas, RS, Brasil.

${ }^{3}$ Instituto Nacional de Investigación Agropecuaria (INIA), Programa Nacional de Investigación en Producción Frutícola, Estación Experimental INIA Las Brujas, Canelones, Uruguay.

${ }^{4}$ Empresa Brasileira de Pesquisa Agropecuária (Embrapa Mandioca e Fruticultura Tropical), Cruz das Almas, BA, Brasil.

ABSTRACT: Diversification of rootstock varieties, with consequent reduction in phytosanitary risks, has great importance to the sustainability of citrus cultivation in the south of Brazil. This study evaluated the performance of 42 rootstocks in the nursery phase to generate 'Valencia Late'sweet orange seedlings. Therefore, nucellar seedlings from the rootstocks under study were analyzed in relation to plant height, stem diameter, mortality rate and percentage of bud set after grafting. The experimental design was completely randomized with four replications of 20 sample units. Not adapted genotypes had high mortality rates, and the ones of both hybrids LCR X CTSW - 009 and LVK X LCR - 038 were $100 \%$ and $90 \%$, respectively. Other 13 genotypes had mortality rates above $30 \%$, and 'Sunki' mandarin was the female genitor of ten of them. 'Swingle' citrumelo was the rootstock with the highest development (plant height and stem diameter), associated with low mortality rate. In relation to the other rootstocks, the best results were the fast grafting diameter, associated with low mortality rate obtained by hybrids HTR - 053, LRF x (LCR x TR) - 005, CLEO x TRBN - 245, CLEO x TRSW - 287, and citrandarins 'Indio', 'Riverside' and 'San Diego', as well as Trifoliate orange and 'Rangpur' lime. In addition to Trifoliate orange, which is widely used in Rio Grande do Sul, these rootstocks have great potential in citriculture in the south of Brazil.

Key words: Citrus spp., adaptation, Poncirus hybrids, propagation, vegetative vigor.

Desempenho em viveiro de porta-enxertos potencialmente promissores para a citricultura do sul do Brasil

RESUMO: A diversificação do uso de variedades porta-enxerto, com a consequente redução de riscos fitossanitários, é de fundamental importância para a sustentabilidade da citricultura do Sul do Brasil. O objetivo deste trabalho foi avaliar o comportamento de 42 portaenxertos na formação de mudas de laranjeira 'Valência Late' em fase de viveiro. Nesse sentido, seedlings (plantas oriundas da germinação de sementes) nucelares dos porta-enxertos estudados foram avaliados relativamente aos caracteres altura da planta, diâmetro do caule, taxa de mortalidade e percentagem de pegamento de borbulhas após a enxertia. O delineamento experimental foi inteiramente casualizado, com quatro repetições de 20 unidades amostrais. Genótipos não adaptados tiveram altas taxas de mortalidade, os híbridos LCR x CTSW - 009 e LVK x LCR - 038 apresentaram 100\% e 90\% de mortalidade, respectivamente. Mais 13 genótipos apresentaram mortalidade superior a 30\%, destes, dez têm como parental feminino a tangerineira 'Sunki'. O citrumelo 'Swingle'foi o porta-enxerto que apresentou maior desenvolvimento (altura da planta e diâmetro do caule), associado a uma baixa taxa de mortalidade. Quanto aos demais porta-enxertos, destacaram-se por atingir rapidamente o diametro de enxertia, associado a baixa taxa de mortalidade, os híbridos HTR - 053, LRF x (LCR x TR) - 005, CLEO $x$ TRBN - 245, CLEO x TRSW - 287, citrandarins 'Indio', 'Riverside'e 'San Diego', assim como o limoeiro 'Cravo'e o Trifoliata. Além do Trifoliata, amplamente utilizado no Rio Grande do Sul, estes porta-enxertos são promissores para a citricultura do Sul do Brasil. Palavras-chave: Citrus spp., adaptação, híbridos de Poncirus, propagação, vigor vegetativo.

\section{INTRODUCTION}

Citriculture is one of the most important agribusiness sectors in Brazil, since the country is the largest producer of sweet oranges [Citrus sinensis (L.) Osbeck] worldwide. Its annual fruit production of $16,713,534 \mathrm{t}$ represents about $35 \%$ of the world's production (FAO, 2018). Rio Grande do Sul (RS) state is the nation's sixth-largest producer, with 352 $451 \mathrm{t}$ per year (IBGE, 2020).

In citrus seedling production, it is fundamental to choose adequate scion and rootstock

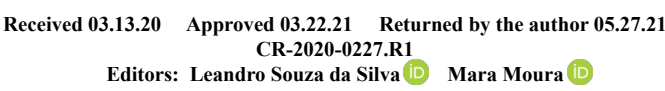


varieties. The latter interferes in plant characteristics, such as vigor, scion size, resistance against pests and diseases, tolerance to environmental stresses, productivity and fruit quality (CRUZ et al., 2019). Good rootstocks should exhibit efficient radicular systems to enable adequate water and nutrient uptake the soil, so as to maintain vital plants' functions and enable them to resist against diseases and tolerate abiotic factors, such as water deficit (SETIN et al., 2009; SARMIENTO et al., 2016).

Rootstocks are grown from seeds, which must be removed from fruits of healthy trees that represent the variety to be multiplied, considering that rootstock development is the longest step in seedling establishment (SARMIENTO et al., 2016). Mean rootstock development time ranges from six to eight months in most Brazilian states. However, in $\mathrm{RS}$, development is slower, where seedling production takes between eight and 24 months, due to the low temperatures in the state (GIRARDI et al., 2010; MARQUES et al., 2019).

Citrus are affected by a large number of pests, which means that much phytosanitary attention is required since the beginning of seedling development. They must be produced in a protected environment, in structures called screened nurseries, by certified nursery people to yield pest-free plants (CARVALHO et al., 2019).

In Brazilian citriculture, 'Rangpur' lime (Citrus limonia Osbeck) is still the most common rootstock, while Trifoliate orange [Poncirus trifoliata (L.) Raf.] predominates in RS because it adapts well to humid soil and tolerates low temperatures (PETRY et al., 2015). Considering this limitation related to the use of rootstocks, it is important to search for diversification and identify the ones that adapt well to edaphic and climatic conditions reported in the south of Brazil, where still depends much on Trifoliate orange. Therefore, the Citrus Breeding Program of Embrapa Cassava \& Fruits (CBP Embrapa), located in Cruz das Almas, Bahia (BA) state, Brazil, has selected new rootstocks in order to increase phytosanitary safety and competitivity in Brazilian citriculture (RODRIGUES et al., 2015).

This study, whose focus was citriculture in the south of Brazil, evaluating the performance of 42 rootstocks in the nursery phase - provided by the CBP Embrapa - in the development of 'Valencia Late' sweet orange trees, so as to identify alternative rootstocks for Trifoliata orange.

\section{MATERIALS AND METHODS}

Evaluations were carried out between September 2016 and February 2018. The first part of the experiment, which was conducted in a glass greenhouse, dealt with the development of rootstocks. The second part, which took place in a screened nursery covered with a milky-white plastic sheet, comprised rootstock transplant and grafting. Both facilities are located in Pelotas, Rio Grande do Sul (RS) State, Brazil (31 ${ }^{\circ} 40^{\prime} 47^{\prime \prime} \mathrm{S}$ and $52^{\circ} 26^{\prime} 24^{\prime \prime} \mathrm{W}$; altitude of $57 \mathrm{~m}$ ).

According to the Köppen climate classification, climate in this region is subtropical humid mesothermal $(\mathrm{Cfb})$, with no dry season and moderate winter. Mean relative air humidity is $80.7 \%$, mean annual precipitation is $1367 \mathrm{~mm}$, and mean annual temperature is $17.8^{\circ} \mathrm{C}$.

Citrus rootstocks seedlings used in the experiment resulted from seeds provided by the CBP Embrapa. Seeds did not undergo any treatment, except a fungicide which aimed at preserving them.

Nucellar seedlings of rootstocks under evaluation were developed in $50-\mathrm{cm}^{3}$ conical tubes, with four longitudinal grooves, suspended on metallic countertops up to their transplant, into 5-L plastic bags in December 2016, which means 220 days after sowing (DAS).

Commercial substrate Turfa Fértil ${ }^{\circledR}$ was used in the seed germination process of the rootstocks. Its $\mathrm{pH}$ was 5.8 , electrical conductivity was $0.7 \mathrm{mS}$ $\mathrm{cm}^{-1}$, maximum humidity was $55 \%$, dry density was $260 \mathrm{~m}^{3}$, and water holding capacity was $60 \%$. Slowrelease fertilizer Osmocote ${ }^{\circledR}(15-10-10)$ was added in the ratio of $10.5 \mathrm{~g}$ to $\mathrm{kg} / \mathrm{substrate}$. In the procedure of rootstock transplant, the substrate in the plastic bags was the one used in the sowing process with the addition of $6.7 \mathrm{~g}$ Osmocote ${ }^{\circledR}(22-4-8)$ and $4.5 \mathrm{~g}$ Osmocote $^{\circledR}(15-10-10)$ to every $\mathrm{kg} /$ substrate.

Irrigation before transplant was carried out on a daily basis while, afterwards, it was conducted every three days - since the container was larger -, except in the first month post-transplant, when daily irrigation was also practiced.

Seedlings were grown with an only stem, and lateral buds were removed weekly. Fertilization was conducted 40, 70, 100 and 190 days after transplant (DAT) with a formula which consisted of 2/3 monoammonium phosphate (11-52-00) and $1 / 3$ calcium nitrate $\mathrm{Ca}\left(\mathrm{NO}_{3}\right)_{2}$. Doses were $2 \mathrm{~g}$ per plant.

Grafting was done by the technique of bud insertion in an inverted-T procedure 365 DAT on rootstocks, whose stem mean diameters (either close to or above $5 \mathrm{~mm}$ ) were appropriate to its objective. Buds from the cultivar Valencia Late were collected from matrices kept in a protected environment in facilities at Embrapa Temperate Climate in Pelotas, RS, Brazil. 
Regarding nucellar seedlings of rootstocks under study, the following variables were evaluated: (1) plant height $(\mathrm{cm})$, the measure of the plant from its basis (limit between root and stem) to the upper end of the apical bud; (2) stem diameter ( $\mathrm{mm}$ ), measured by a digital pachymeter, three $\mathrm{cm}$ above the plant basis; (3) percentage of plant mortality (\%); and (4) percentage of bud attachment 60 days after grafting (\%). Concerning plant mortality, three categories were considered: low (below 5\%), medium (between $5 \%$ and $15 \%$ ) and high (above $15 \%$ ).

Table 1 shows the 42 studied rootstocks. The descriptions of the abbreviations that make up the name of the rootstocks, as well as the species to which they belong are described in table 2 . Was used a completely randomized design, with four replicates, and each one was composed of 20 sample units.

Data were submitted to the analysis of variance (ANOVA) with the use of the F-test. When results were significant, data on plant height, stem diameter and plant mortality were submitted to the SCOTT \& KNOTT (1975) clustering algorithm, at $\mathrm{p} \leq 0.05$ significance level, by the Infostat statistical program. Data on bud attachment after grafting were submitted to the Tukey's test, at $\mathrm{p} \leq 0.05$ probability level, with the use of the Sisvar 5.6 statistical program. Percentage values were transformed by the expression arc sen to meet the requirement of variances' homogeneity and residuals' normality, preconized by the ANOVA. However, the results are shown in the original scale of these variables.

\section{RESULTS AND DISCUSSION}

Evaluations, carried out 130, 160 and 190 DAS, showed that Trifoliate orange was the tallest rootstock. Regarding stem diameter, Trifoliate orange and 'Swingle' citrumelo exhibited the highest values (Table 3). Height and stem diameter means of Trifoliate orange were $5.8 \mathrm{~cm}$ and $2.4 \mathrm{~mm} 130$ DAS, respectively, and $8.5 \mathrm{~cm}$ and $2.5 \mathrm{~mm} 160 \mathrm{DAS}$, respectively. In this period, this rootstock stood out because it had the highest growth soon after the end of the germinative period.

Trifoliate orange, the rootstock which had the highest initial growth (up to 160 DAS), did not exhibited heights above the ones reported by other studies. TEIXEIRA et al. (2009) also reported, in their study in RS, $27.15 \mathrm{~cm}$ in height and 2.15 in stem diameter 150 DAS, where plants were higher than the ones analyzed by this study. It should be highlighted that the study conducted by TEIXEIRA et al. (2009) took place in a warmer region, in Eldorado do Sul,
$\mathrm{RS}$, where the mean annual temperature is $3.6^{\circ} \mathrm{C}$ higher than the one found in Pelotas, RS. Results showed that adapted rootstocks, such as Trifoliate orange, tend to produce shorter seedlings at low temperatures. However, stem diameters are not smaller by comparison with the ones found at high temperatures. It does not represent a problem, since RODRIGUES et al. (2016) stated that stem diameter is the variable that determines time for grafting. Thus, this variable exhibits satisfactory values and does not affect the process of seedling development, even though they may be shorter.

Rootstock transplant from tubes to plastic bags took place 220 DAS. It was delayed 65 days, when comparing time reported by PAROLIN et al. (2017). These authors studied 15 genotypes investigated by this study and transplanted seedlings to plastic bags 155 DAS in Bebedouro, São Paulo (SP) state, a region that is warmer than the one of this study (mean annual temperature is about $4.5^{\circ} \mathrm{C}$ higher). According to MONTEIRO (2009), plants grow slower at low temperatures while, in winter, growth is almost null. Delay in transplanting shows that seedlings take more time to be produced in the south of Brazil. Thus, nursery people in subtropical regions must consider the need for more time in this process than the ones that work in warmer regions.

Excellent development of stem diameters of some rootstocks should be highlighted, since it enabled precocious grafting to be researched. Stem diameters of 'San Diego' (4.2 mm) and 'Indio' (4.4 $\mathrm{mm}$ ) citrandarins, besides 'Swingle' citrumelo (5.4 mm), grown in Pelotas, RS, evaluated 80 DAT (Table 4), had higher values than the ones reported by RODRIGUES et al. (2016). As reported by these authors, means of stem diameters measured $10 \mathrm{~cm}$ above the plant basis were $4.1 \mathrm{~mm}$ for both citrandarins, 'Indio' and 'San Diego', while the one of 'Swingle' citrumelo was $4.8 \mathrm{~mm}$. They grew in Cruz das Almas, BA, and were evaluated 90 DAT. It should be emphasized that this city is a region where citrus seedlings with high precocity have been produced. Thus, this fact is an evidence of the good adaptation of these rootstocks to the climate conditions found in Pelotas, RS. Even though rootstocks from Cruz das Almas, BA, were higher - heights ranged from 10 to $20 \mathrm{~cm}$, depending on the genotype - than the ones grown in RS, the latter were more robust, considering the same time period. Similarities can be reported between these rootstocks and Trifoliate orange, since plants are smaller and stem diameters are equal or larger than the ones from seedlings developed in warmer regions. It has been observed that rootstocks that adapt to low temperatures are smaller; however, their stem diameters - the most important variable 
Table 1 - Rootstocks used in the research.

\begin{tabular}{|c|c|}
\hline $\begin{array}{l}\text { Number corresponding to } \\
\text { the rootstock }\end{array}$ & Rootstock \\
\hline 1 & TSKC x CTSW $-025^{1}$ \\
\hline 2 & TSKC x CTSW - $028^{1}$ \\
\hline 3 & TSKC x CTSW $-031^{1}$ \\
\hline 4 & TSKC x CTSW - $033^{1}$ \\
\hline 5 & TSKC x CTSW - $036^{1}$ \\
\hline 6 & TSKC $x$ CTSW $-041^{1}$ \\
\hline 7 & TSKC $\mathrm{x}$ TRFD $-003^{1}$ \\
\hline 8 & TSKC $x$ TRFD $-006^{1}$ \\
\hline 9 & TSKC $x$ TRFD $-007^{1}$ \\
\hline 10 & TSKC x CTCM - $008^{1}$ \\
\hline 11 & TSKC x CTTR $-002^{1}$ \\
\hline 12 & TSKC $x$ CTTR $-029^{1}$ \\
\hline 13 & TSKC $\mathrm{x}$ TRBK $-006^{1}$ \\
\hline 14 & TSKC $x$ TRBK $-\mathrm{CO}^{1}$ \\
\hline 15 & TSKC $x($ LCR $x$ TR $)-001^{1}$ \\
\hline 16 & TSKC $x($ LCR $x$ TR $)-020^{1}$ \\
\hline 17 & TSKC $\mathrm{x}(\mathrm{LCR} \times \mathrm{TR})-040^{1}$ \\
\hline 18 & TSKC $x($ LCR $x$ TR $)-059^{1}$ \\
\hline 19 & TSKC $x($ LCR $x$ TR $)-073^{1}$ \\
\hline 20 & TSKFL x CTSW $-004^{1}$ \\
\hline 21 & LRF $x($ LCR $x$ TR $)-005^{1}$ \\
\hline 22 & LCR $x$ CTSW $-009^{1}$ \\
\hline 23 & LCR $x$ TR $-001^{1}$ \\
\hline 24 & LVK $x$ LCR $-038^{1}$ \\
\hline 25 & LVK $x$ LVA $-009^{1}$ \\
\hline 26 & HTR $-051^{1}$ \\
\hline 27 & HTR $-053^{1}$ \\
\hline 28 & HTR $-069^{1}$ \\
\hline 29 & HTR $-116^{1}$ \\
\hline 30 & HTR $-207^{1}$ \\
\hline 31 & HTR $-208^{1}$ \\
\hline 32 & MXWL x LHA - $001^{1}$ \\
\hline 33 & CLEO $\times$ TRBN $-245^{2}$ \\
\hline 34 & CLEO $x$ TRSW $-287^{2}$ \\
\hline 35 & 'Indio' citrandarin ${ }^{2}$ \\
\hline 36 & 'Riverside' citrandarin ${ }^{2}$ \\
\hline 37 & 'San Diego' citrandarin ${ }^{2}$ \\
\hline 38 & 'Fepagro C - 13' citrange \\
\hline 39 & 'Swingle' citrumelo \\
\hline 40 & Trifoliate orange \\
\hline 41 & 'Sunki Tropical' mandarin \\
\hline 42 & 'Rangpur' lime \\
\hline
\end{tabular}

${ }^{1}$ Hybrid obtained by the Citrus Breeding Program of Embrapa Cassava \& Fruits (CBP Embrapa), Cruz das Almas, BA, Brazil.

${ }^{2}$ Hybrid obtained by the United States Department of Agriculture (USDA). related to grafting, according to RODRIGUES et al. (2016) - exhibit satisfactory values.

At the beginning of autumn, when temperatures dropped, 80 DAT, genotype LCR x CTSW - 009 exhibited 5\% plant mortality (Table 4), and this rate increased in the following months. In winter, 180 DAT, higher mortality rates were reported for genotypes LCR x CTSW - 009 (32.2\%), TSKC x CTSW - 031 (26.5\%), LVK x LCR - 038 (15.0\%) and MXML X LHA - 001 (12.5\%) (Table 4).

Citrus production at low temperatures requires more attention to genotype adaptation. For instance, genotype LVK x LCR - 038 led to plants with $15.4 \mathrm{~cm}$ in height and $3.5 \mathrm{~mm}$ in stem diameter 80 DAT. Low growth is not intrinsic to this genotype, as RODRIGUES et al. (2016) studied it in Cruz das Almas, BA, a warmer region, and registered 47.5 $\mathrm{cm}$ in height and $4.5 \mathrm{~mm}$ in stem diameter 80 DAT. PAROLIN et al. (2017) also studied it in Bebedouro, $\mathrm{SP}$, and reported plants with $85.0 \mathrm{~cm}$ in height and 6.1 $\mathrm{mm}$ in stem diameter 99 DAT. It is evident that this genotype does not adapt well to low temperatures. It is likely to happen because this genotype has the lemon tree 'Volkameriano' [Citrus volkameriana (Risso) V. Ten. \& Pasq.] in its genetic constitution. It also bestowed low growth, associated with high mortality, to seedlings of rootstocks in the nursery phase (under investigation by this study). It showed that genotypes that descend from the lemon tree 'Volkameriano' are appropriate neither to subtropical regions nor to temperate ones.

The 'Rangpur' lime exhibited $35.3 \mathrm{~cm}$ in height and $4.8 \mathrm{~mm}$ in stem diameter 180 DAT (Table 4). According to PEREZ et al. (2017), this genotype, in subtropical regions, grows slow and its plants are small because it is sensitive to cold weather. Even though the literature shows low adaptation of the 'Rangpur' lime to subtropical regions, this study had different results, since the rootstock exhibited higher growth and less mortality than most genotypes in the nursery phase investigated in Pelotas, RS.

Significant increase in values of plant height and stem diameter was found 320 DAT for the hybrids 'Swingle' citrumelo, 'Indio', 'Riverside', 'San Diego' and CLEO x TRSW - 287 citrandarins, besides the LRF x (LCR x TR) - 005 citrimoniambhiri. Regarding growth, these genotypes outdid Trifoliate orange, while the other genotypes resumed growth, Trifoliate orange kept in hibernal dormancy, a characteristic of this rootstock which is related to its good tolerance to cold weather (OUSTRIC et al., 2017).

In winter, mortality percentages increased in genotypes LCR x CTSW - 009, TSKC x CTSW - 031 
Table 2 - Meaning of abbreviations and species.

\begin{tabular}{|c|c|}
\hline Genotype or abbreviation & Meaning of abbreviations and/or species involved \\
\hline TSKC & Common 'Sunki' mandarin [Citrus sunki (Hayata) hort. ex Tanaka] \\
\hline CTTR & 'Troyer' citrange [Citrus sinensis (L.) Osbeck x Poncirus trifoliata (L.) Raf.] \\
\hline LVK & 'Volkamer' lemon [Citrus volkameriana (Risso) V. Ten. \& Pasq.] \\
\hline LVA & 'Valência' sweet orange (C. sinensis) \\
\hline 'Indio', 'Riverside' and 'San Diego' citrandarins & C. sunki $\mathrm{x} P$. trifoliate \\
\hline TRFD & $\begin{array}{c}\text { 'Flying Dragon' trifoliate orange }[P . \text { trifoliata }(\mathrm{L} .) \text { Raf. var. monstrosa (T. Ito) } \\
\text { Swingle }]\end{array}$ \\
\hline TRBK & 'Beneke' trifoliate orange ( $P$. trifoliata $)$ \\
\hline MXWL & ‘Willowleaf’ mandarin (Citrus deliciosa Ten.) \\
\hline LHA & 'Hamlin' sweet orange (C. sinensis) \\
\hline CTSW & 'Swingle' citrumelo [Citrus paradisi Macfad. x P. trifoliata] \\
\hline CLEO & 'Cleópatra’ mandarin (Citrus reshni hort. ex Tanaka) \\
\hline TRBN & 'Barnes' trifoliate Orange \\
\hline 'Sunki Tropical' mandarin & C. sunki \\
\hline CTCM & 'Coleman' citrange \\
\hline TRSW & 'Swingle' trifoliate orange \\
\hline LCR & ‘Rangpur’ lime (Citrus limonia Osbeck) \\
\hline TR & Trifoliate orange \\
\hline TSKFL & 'Sunki da Flórida' mandarin (C. sunki) \\
\hline HTR & Trifoliate hybrid \\
\hline LRF & 'Florida Rough’ lemon (Citrus jambhiri Lush.) \\
\hline
\end{tabular}

and MXML - LHA - 001, reaching about 40\%, while hybrids LVK x LCR - 038 and TSKC x CTSW - 025 had about $20 \%$ mortality. At the end of winter, in September, 260 DAT, the hybrid LCR x CTSW - 009 had $100 \%$ mortality.

In December, 365 DAT, only 15 genotypes exhibited plants that could be used for grafting. The time period taken by more precocious rootstocks to reach grafting readiness is much higher than the one reported by other studies of citrus rootstocks. PASSOS et al. (2006), in studies carried out in Cruz das Almas, BA, and PAROLIN et al. (2017), in Bebedouro, SP, reported that rootstocks were again able to grafting after 210 DAT and 99 DAT, respectively. It reinforces the thesis that citrus nursery people in subtropical regions should plan their work differently from their counterparts in tropical regions. Taking into account that citrus seedlings take more time to develop in subtropical regions, they need large facilities seedlings stay much longer in the nursery and take up more space - and nutrition costs are higher in this phase. This study showed that the needed period to produce citrus seedlings is 365 DAT in subtropical regions. When this period is established, nursery people can synchronize the time when the seedlings are ready and the period of highest demand in the region.
Seven rootstocks exhibited about 90\% of plants in grafting conditions: Trifoliate orange, 'Swingle' citrumelo, 'Indio', 'San Diego', CLEO x TRBN - 245 and CLEO x TRSW - 287 citrandarins and LRF $x$ (LCR x TR) - 005 citrimoniambhiri (Figure 1); the latter was registered by Embrapa, in the National Register of Cultivars (NRC) of the Brazilian Ministry of Agriculture, Livestock and Food Supply (MALFS), under the name BRS N Gimenes Fernandes. Two genotypes had about $60 \%$ of grafted plants: TSKC x CTSW - 036 and TSKC x CTSW - 041 (Figure 1); the latter, a citrumelandarin, was registered by Embrapa, in the NRC-MALFS, under the name BRS Cunha Sobrinho. PEREZ et al. (2017) described Trifoliate orange as a species that was well-adapted to the climate in southern Brazil. Its tolerance for cold weather explains the high percentage of plants capable of grafting, and it should be highlighted that this rootstock is the predominant one in the extreme south of Brazil.

Great variations were observed in grafting attachment. CLEO x TRNB - 245, CLEO x TRSW - 287 and HTR - 053 (citrangor registered by Embrapa, in the NRC-MALFS, under the name BRS O S Passos) had percentages around 90\%, while TSKC x CTSW - 041 exhibited about $20 \%$ (Figure 1). According to BARON 
Table 3 - Height (HE) and stem diameter (DT) of 42 citrus rootstocks 130, 160 and 190 days after sowing (DAS).

\begin{tabular}{|c|c|c|c|c|c|c|}
\hline \multirow[t]{2}{*}{ Rootstock } & \multicolumn{2}{|c|}{----------------130 DAS---------------- } & \multicolumn{2}{|c|}{-------------160 DAS------------- } & \multicolumn{2}{|c|}{--------------190 DAS---- } \\
\hline & $\begin{array}{c}\mathrm{HE} \\
(\mathrm{cm})\end{array}$ & $\begin{array}{c}\text { DT } \\
(\mathrm{mm})\end{array}$ & $\begin{array}{l}\mathrm{HE} \\
(\mathrm{cm})\end{array}$ & $\begin{array}{c}\text { DT } \\
(\mathrm{mm})\end{array}$ & $\begin{array}{c}\mathrm{HE} \\
(\mathrm{cm})\end{array}$ & $\begin{array}{c}\text { DT } \\
(\mathrm{mm})\end{array}$ \\
\hline 1 & $2.27 f$ & $1.29 \mathrm{e}$ & $4.08 \mathrm{e}$ & $1.63 \mathrm{e}$ & $5.89 \mathrm{~d}$ & $1.77 \mathrm{e}$ \\
\hline 2 & $2.83 \mathrm{e}$ & $0.69 \mathrm{~g}$ & $4.57 \mathrm{e}$ & $1.47 \mathrm{f}$ & $5.49 \mathrm{e}$ & $1.72 \mathrm{e}$ \\
\hline 3 & $2.93 \mathrm{e}$ & $1.65 \mathrm{c}$ & $4.16 \mathrm{e}$ & $1.81 \mathrm{~d}$ & $5.59 \mathrm{~d}$ & $1.97 \mathrm{~d}$ \\
\hline 4 & $2.33 f$ & $1.15 \mathrm{f}$ & $2.69 f$ & $1.45 \mathrm{f}$ & $4.03 \mathrm{f}$ & $1.74 \mathrm{e}$ \\
\hline 5 & $1.71 \mathrm{~g}$ & $1.24 \mathrm{f}$ & $3.36 f$ & $1.45 \mathrm{f}$ & $4.92 \mathrm{e}$ & $1.57 \mathrm{e}$ \\
\hline 6 & $2.77 \mathrm{e}$ & $1.42 \mathrm{~d}$ & $3.98 \mathrm{e}$ & $1.61 \mathrm{e}$ & $5.36 \mathrm{e}$ & $1.92 \mathrm{~d}$ \\
\hline 7 & $3.62 \mathrm{~d}$ & $1.66 \mathrm{c}$ & $5.75 \mathrm{c}$ & $1.89 \mathrm{c}$ & $8.00 \mathrm{c}$ & $2.03 \mathrm{~d}$ \\
\hline 8 & $3.75 \mathrm{~d}$ & $1.49 \mathrm{~d}$ & $5.36 \mathrm{~d}$ & $1.74 \mathrm{~d}$ & $7.66 \mathrm{c}$ & $1.90 \mathrm{~d}$ \\
\hline 9 & $2.84 \mathrm{e}$ & $1.15 \mathrm{f}$ & $3.74 \mathrm{e}$ & $1.61 \mathrm{e}$ & $5.26 \mathrm{e}$ & $1.94 \mathrm{~d}$ \\
\hline 10 & $3.11 \mathrm{e}$ & $1.36 \mathrm{e}$ & $3.84 \mathrm{e}$ & $1.88 \mathrm{c}$ & $4.84 \mathrm{e}$ & $2.11 \mathrm{c}$ \\
\hline 11 & $4.54 \mathrm{~b}$ & $1.14 \mathrm{f}$ & $5.48 d$ & $1.74 d$ & $7.12 \mathrm{c}$ & $1.95 \mathrm{~d}$ \\
\hline 12 & $4.63 b$ & $1.36 \mathrm{e}$ & $5.57 \mathrm{c}$ & $1.63 \mathrm{e}$ & $6.52 \mathrm{~d}$ & $1.80 \mathrm{e}$ \\
\hline 13 & $4.68 b$ & $1.29 \mathrm{e}$ & $5.18 \mathrm{~d}$ & $1.75 \mathrm{~d}$ & $7.42 \mathrm{c}$ & $2.13 \mathrm{c}$ \\
\hline 14 & $3.70 \mathrm{~d}$ & $1.66 \mathrm{c}$ & $5.93 \mathrm{c}$ & $1.81 \mathrm{~d}$ & $7.46 \mathrm{c}$ & $2.03 \mathrm{~d}$ \\
\hline 15 & $1.93 \mathrm{~g}$ & $1.33 \mathrm{e}$ & $3.06 \mathrm{f}$ & $1.54 \mathrm{f}$ & $3.73 \mathrm{f}$ & $1.70 \mathrm{e}$ \\
\hline 16 & $2.51 \mathrm{f}$ & $1.37 \mathrm{e}$ & $4.02 \mathrm{e}$ & $1.66 \mathrm{e}$ & $5.08 \mathrm{e}$ & $1.70 \mathrm{e}$ \\
\hline 17 & $2.09 \mathrm{~g}$ & $1.44 d$ & $3.17 \mathrm{f}$ & $1.58 \mathrm{e}$ & $3.86 f$ & $1.74 \mathrm{e}$ \\
\hline 18 & $4.90 \mathrm{~b}$ & $1.64 \mathrm{c}$ & $6.09 \mathrm{c}$ & $1.96 \mathrm{c}$ & $7.64 c$ & $2.34 \mathrm{~b}$ \\
\hline 19 & $2.41 \mathrm{f}$ & $1.41 \mathrm{~d}$ & $2.82 \mathrm{f}$ & $1.51 \mathrm{f}$ & $4.49 f$ & $1.79 \mathrm{e}$ \\
\hline 20 & $4.31 b$ & $1.41 \mathrm{~d}$ & $5.81 \mathrm{c}$ & $1.88 \mathrm{c}$ & $7.68 \mathrm{c}$ & $2.01 \mathrm{~d}$ \\
\hline 21 & $3.40 \mathrm{~d}$ & $1.56 \mathrm{c}$ & $5.02 \mathrm{~d}$ & $1.83 \mathrm{c}$ & $6.88 \mathrm{c}$ & $1.96 \mathrm{~d}$ \\
\hline 22 & $3.77 \mathrm{~d}$ & $1.51 \mathrm{~d}$ & $5.27 \mathrm{~d}$ & $1.77 \mathrm{~d}$ & $6.81 \mathrm{c}$ & $1.86 \mathrm{~d}$ \\
\hline 23 & $2.49 f$ & $1.18 \mathrm{f}$ & $3.88 \mathrm{e}$ & $1.58 \mathrm{e}$ & $5.08 \mathrm{e}$ & $1.75 \mathrm{e}$ \\
\hline 24 & $4.04 \mathrm{c}$ & $1.75 \mathrm{c}$ & $5.32 \mathrm{~d}$ & $2.08 b$ & $6.44 d$ & $2.29 \mathrm{~b}$ \\
\hline 25 & $3.56 \mathrm{~d}$ & $1.20 \mathrm{f}$ & $4.61 \mathrm{e}$ & $1.58 \mathrm{e}$ & $5.40 \mathrm{e}$ & $2.03 \mathrm{~d}$ \\
\hline 26 & $3.72 \mathrm{~d}$ & $1.55 \mathrm{c}$ & $5.18 \mathrm{~d}$ & $1.88 \mathrm{c}$ & $7.45 \mathrm{c}$ & $2.11 \mathrm{c}$ \\
\hline 27 & $2.88 \mathrm{f}$ & $1.34 \mathrm{e}$ & $3.63 \mathrm{e}$ & $1.57 \mathrm{e}$ & $5.14 \mathrm{e}$ & $1.68 \mathrm{e}$ \\
\hline 28 & $2.75 \mathrm{e}$ & $1.16 \mathrm{f}$ & $3.20 \mathrm{f}$ & $1.49 \mathrm{f}$ & $4.39 f$ & $1.87 \mathrm{~d}$ \\
\hline 29 & $3.46 \mathrm{~d}$ & $1.32 \mathrm{e}$ & $4.78 \mathrm{~d}$ & $1.70 \mathrm{~d}$ & $6.14 \mathrm{~d}$ & $2.00 \mathrm{~d}$ \\
\hline 30 & $3.80 \mathrm{~d}$ & $1.63 \mathrm{c}$ & $5.19 \mathrm{~d}$ & $1.92 \mathrm{c}$ & $7.26 \mathrm{c}$ & $2.16 \mathrm{c}$ \\
\hline 31 & $4.50 \mathrm{c}$ & $1.73 c$ & $6.22 \mathrm{c}$ & $2.05 \mathrm{~b}$ & $7.95 \mathrm{c}$ & $2.30 \mathrm{~b}$ \\
\hline 32 & $2.86 \mathrm{e}$ & $1.19 \mathrm{f}$ & $4.16 \mathrm{e}$ & $1.66 \mathrm{e}$ & $5.78 \mathrm{~d}$ & $1.90 \mathrm{~d}$ \\
\hline 33 & $4.04 c$ & $1.33 \mathrm{e}$ & $5.22 \mathrm{~d}$ & $1.77 \mathrm{~d}$ & $6.45 \mathrm{~d}$ & $2.11 \mathrm{c}$ \\
\hline 34 & $4.07 \mathrm{c}$ & $1.45 \mathrm{~d}$ & $5.45 d$ & $1.76 \mathrm{~d}$ & $7.28 \mathrm{c}$ & $2.08 \mathrm{c}$ \\
\hline 35 & $4.29 b$ & $1.33 \mathrm{e}$ & $5.23 \mathrm{~d}$ & $1.75 \mathrm{~d}$ & $6.07 d$ & $1.96 \mathrm{~d}$ \\
\hline 36 & $4.36 \mathrm{~b}$ & $1.30 \mathrm{e}$ & $5.31 \mathrm{~d}$ & $1.77 \mathrm{~d}$ & $6.26 \mathrm{~d}$ & $1.99 \mathrm{~d}$ \\
\hline 37 & $3.38 \mathrm{~d}$ & $1.51 \mathrm{~d}$ & $4.73 d$ & $1.76 \mathrm{~d}$ & $6.28 \mathrm{~d}$ & $1.98 \mathrm{~d}$ \\
\hline 38 & $4.55 b$ & $1.43 \mathrm{~d}$ & $5.12 \mathrm{~d}$ & $1.90 \mathrm{c}$ & $6.58 \mathrm{~d}$ & $2.01 \mathrm{~d}$ \\
\hline 39 & $4.91 b$ & $2.17 b$ & $7.68 b$ & $2.48 \mathrm{a}$ & $9.58 b$ & $2.70 \mathrm{a}$ \\
\hline 40 & $5.75 a$ & $2.41 \mathrm{a}$ & $8.47 \mathrm{a}$ & $2.51 \mathrm{a}$ & $13.70 \mathrm{a}$ & $2.63 \mathrm{a}$ \\
\hline 41 & $3.06 \mathrm{e}$ & $1.30 \mathrm{e}$ & $4.09 \mathrm{e}$ & $1.65 \mathrm{e}$ & $5.12 \mathrm{e}$ & $1.83 \mathrm{e}$ \\
\hline 42 & $4.59 \mathrm{~b}$ & $1.56 \mathrm{c}$ & $7.38 \mathrm{~b}$ & $1.84 \mathrm{c}$ & $9.35 b$ & $2.16 \mathrm{c}$ \\
\hline
\end{tabular}

Means followed by the same letter in a column belong to the same group by the Scott-Knott clustering algorithm $(\mathrm{P} \leq 0.05)$.

et al. (2019), compatibility between grafted genetic material and conditions of rootstock development is one of the main factors that influence bud attachment in grafting.
Trifoliate orange exhibited good values for plants which were ready for grafting. However, it did not surpass the others, such as the 'Swingle' citrumelo rootstock, in terms of plant height and stem diameter. Trifoliate orange 
Table 4 - Height (HE), stem diameter (DT) and mortality rate (MT) of 42 citrus rootstocks 30, 80, 180 and 320 days after transplant (DAT).

\begin{tabular}{|c|c|c|c|c|c|c|c|c|c|c|c|}
\hline \multirow[t]{2}{*}{ Rootstock } & \multicolumn{2}{|c|}{----------30 DAT--------- } & \multicolumn{3}{|c|}{------------80 DAT------------ } & \multicolumn{3}{|c|}{-----------180 DAT------------ } & \multicolumn{3}{|c|}{------------320 DAT----------- } \\
\hline & $\begin{array}{c}\mathrm{HE} \\
(\mathrm{cm})\end{array}$ & $\begin{array}{c}\text { DT } \\
(\mathrm{mm})\end{array}$ & $\begin{array}{c}\mathrm{HE} \\
(\mathrm{cm})\end{array}$ & $\begin{array}{c}\text { DT } \\
(\mathrm{mm})\end{array}$ & $\begin{array}{l}\text { MT } \\
(\%)\end{array}$ & $\begin{array}{l}\mathrm{HE} \\
(\mathrm{cm})\end{array}$ & $\begin{array}{c}\text { DT } \\
(\mathrm{mm})\end{array}$ & $\begin{array}{l}\text { MT } \\
(\%)\end{array}$ & $\begin{array}{c}\mathrm{HE} \\
(\mathrm{cm})\end{array}$ & $\begin{array}{c}\text { DT } \\
(\mathrm{mm})\end{array}$ & $\begin{array}{l}\text { MT } \\
(\%)\end{array}$ \\
\hline 1 & $19.09 \mathrm{e}$ & $3.34 \mathrm{~g}$ & $19.09 \mathrm{e}$ & $3.34 \mathrm{~g}$ & 0.00 & $22.21 \mathrm{~g}$ & $3.74 \mathrm{e}$ & 5.00 & 39.89 & $5.34 \mathrm{f}$ & 50.00 \\
\hline 2 & $15.28 \mathrm{f}$ & $2.53 \mathrm{j}$ & $15.28 \mathrm{f}$ & $2.53 \mathrm{j}$ & 0.00 & $16.98 \mathrm{~h}$ & $3.11 \mathrm{~g}$ & 1.92 & $33.03 \mathrm{e}$ & $4.66 \mathrm{~g}$ & 44.22 \\
\hline 3 & $13.07 \mathrm{~g}$ & $2.64 \mathrm{i}$ & $13.07 \mathrm{~g}$ & $2.64 \mathrm{i}$ & 0.00 & $15.00 \mathrm{i}$ & $3.13 \mathrm{~g}$ & 26.47 & $18.93 \mathrm{~g}$ & $3.72 \mathrm{~h}$ & 81.65 \\
\hline 4 & $15.68 f$ & $2.49 \mathrm{j}$ & $15.68 \mathrm{f}$ & $2.49 \mathrm{j}$ & 0.00 & $17.44 \mathrm{~h}$ & $2.94 \mathrm{~h}$ & 0.00 & $26.71 \mathrm{f}$ & $4.04 \mathrm{~h}$ & 18.75 \\
\hline 5 & $16.62 \mathrm{e}$ & $2.67 \mathrm{i}$ & $16.62 \mathrm{e}$ & $2.67 \mathrm{i}$ & 0.00 & $22.10 \mathrm{~g}$ & $3.74 \mathrm{e}$ & 0.00 & $40.51 \mathrm{~d}$ & $5.12 \mathrm{~g}$ & 7.50 \\
\hline 6 & $30.14 b$ & $3.00 \mathrm{~h}$ & $30.14 b$ & $3.00 \mathrm{~h}$ & 0.00 & $31.86 \mathrm{c}$ & $3.75 \mathrm{e}$ & 1.25 & $46.24 c$ & $4.59 \mathrm{~g}$ & 15.00 \\
\hline 7 & $32.14 b$ & $4.05 \mathrm{~d}$ & $32.14 b$ & $4.05 \mathrm{~d}$ & 0.00 & $32.33 \mathrm{c}$ & $4.23 \mathrm{~d}$ & 0.00 & $36.71 \mathrm{e}$ & $5.42 \mathrm{f}$ & 8.75 \\
\hline 8 & $15.79 \mathrm{c}$ & $3.63 \mathrm{f}$ & $15.79 \mathrm{c}$ & $3.63 \mathrm{f}$ & 0.00 & $26.61 \mathrm{e}$ & $4.10 \mathrm{~d}$ & 1.25 & $31.44 \mathrm{e}$ & $4.75 \mathrm{~g}$ & 43.75 \\
\hline 9 & $23.21 \mathrm{~d}$ & $2.65 \mathrm{i}$ & $23.21 \mathrm{~d}$ & $2.65 \mathrm{i}$ & 0.00 & $24.90 f$ & $3.53 \mathrm{f}$ & 0.00 & $29.61 f$ & $4.33 \mathrm{~h}$ & 28.13 \\
\hline 10 & $12.24 \mathrm{~g}$ & $2.51 \mathrm{j}$ & $12.24 \mathrm{~g}$ & $2.51 \mathrm{j}$ & 0.00 & $14.55 \mathrm{i}$ & $2.82 \mathrm{~h}$ & 7.14 & $25.81 \mathrm{f}$ & $4.26 \mathrm{~h}$ & 32.13 \\
\hline 11 & $28.23 c$ & $3.96 \mathrm{e}$ & $28.23 \mathrm{c}$ & $3.96 \mathrm{e}$ & 0.00 & $29.39 d$ & $4.29 \mathrm{~d}$ & 3.75 & $32.57 \mathrm{e}$ & $5.01 \mathrm{~g}$ & 48.75 \\
\hline 12 & $22.25 \mathrm{~d}$ & $2.90 \mathrm{~h}$ & $22.25 d$ & $2.90 \mathrm{~h}$ & 0.00 & $23.52 \mathrm{f}$ & $3.14 \mathrm{~g}$ & 0.00 & $29.57 f$ & $3.85 \mathrm{~h}$ & 73.75 \\
\hline 13 & $29.49 b$ & $3.70 \mathrm{f}$ & $29.49 b$ & $3.70 \mathrm{f}$ & 0.00 & $31.30 \mathrm{c}$ & $4.04 d$ & 0.00 & $44.98 \mathrm{c}$ & $5.35 f$ & 7.50 \\
\hline 14 & $23.08 \mathrm{~d}$ & $2.97 \mathrm{~h}$ & $23.08 \mathrm{~d}$ & $2.97 \mathrm{~h}$ & 0.00 & $24.09 \mathrm{f}$ & $3.43 \mathrm{f}$ & 1.25 & $39.59 \mathrm{~d}$ & $4.70 \mathrm{~g}$ & 7.50 \\
\hline 15 & $19.07 \mathrm{e}$ & $2.81 \mathrm{i}$ & $19.07 \mathrm{e}$ & $2.81 \mathrm{i}$ & 0.00 & $21.57 \mathrm{~g}$ & $3.21 \mathrm{~g}$ & 0.00 & $39.56 \mathrm{~d}$ & $4.52 \mathrm{~h}$ & 0.00 \\
\hline 16 & $11.28 \mathrm{~g}$ & $2.61 \mathrm{j}$ & $11.28 \mathrm{~g}$ & $2.61 \mathrm{j}$ & 0.00 & $12.68 \mathrm{i}$ & $2.96 \mathrm{~h}$ & 5.00 & $19.19 \mathrm{~g}$ & $3.93 \mathrm{~h}$ & 42.50 \\
\hline 17 & $12.79 \mathrm{~g}$ & $2.35 \mathrm{j}$ & $12.79 \mathrm{~g}$ & $2.35 \mathrm{j}$ & 0.00 & $14.10 \mathrm{i}$ & $2.60 \mathrm{~h}$ & 7.50 & $19.83 \mathrm{~g}$ & $3.42 \mathrm{~h}$ & 43.75 \\
\hline 18 & $30.05 b$ & $3.76 \mathrm{f}$ & $30.05 b$ & $3.76 \mathrm{f}$ & 0.00 & $31.60 \mathrm{c}$ & $4.04 \mathrm{~d}$ & 1.25 & $34.85 \mathrm{e}$ & $4.90 \mathrm{~g}$ & 8.75 \\
\hline 19 & $14.04 \mathrm{f}$ & $2.85 \mathrm{i}$ & $14.04 f$ & $2.85 \mathrm{i}$ & 0.00 & $15.04 \mathrm{i}$ & $3.05 \mathrm{~g}$ & 2.50 & $24.88 \mathrm{f}$ & $4.09 \mathrm{~h}$ & 33.75 \\
\hline 20 & $15.65 \mathrm{f}$ & $2.83 \mathrm{i}$ & $15.65 f$ & $2.83 \mathrm{i}$ & 0.00 & $16.27 \mathrm{~h}$ & $3.10 \mathrm{~g}$ & 1.25 & $17.17 \mathrm{~g}$ & $4.18 \mathrm{~h}$ & 12.50 \\
\hline 21 & $31.17 b$ & $3.90 \mathrm{e}$ & $31.17 \mathrm{~b}$ & $3.90 \mathrm{e}$ & 0.00 & $34.31 \mathrm{~b}$ & $4.69 c$ & 1.25 & $63.29 \mathrm{a}$ & $7.37 \mathrm{c}$ & 1.38 \\
\hline 22 & $11.83 \mathrm{~g}$ & $2.74 \mathrm{i}$ & $11.83 \mathrm{~g}$ & $2.74 \mathrm{i}$ & 5.00 & $12.93 \mathrm{i}$ & $3.14 \mathrm{~g}$ & 36.25 & & & 100 \\
\hline 23 & $14.53 \mathrm{f}$ & $2.54 \mathrm{j}$ & $14.53 f$ & $2.54 \mathrm{j}$ & 0.00 & $15.28 \mathrm{i}$ & $2.90 \mathrm{~h}$ & 3.13 & $26.75 f$ & $4.13 \mathrm{~h}$ & 43.75 \\
\hline 24 & $15.39 \mathrm{f}$ & $3.51 \mathrm{f}$ & $15.39 \mathrm{f}$ & $3.51 \mathrm{f}$ & 0.00 & $17.22 \mathrm{~h}$ & $4.13 \mathrm{~d}$ & 15.00 & $25.57 f$ & $5.12 \mathrm{~g}$ & 90.00 \\
\hline 25 & $15.94 f$ & $3.29 \mathrm{~g}$ & $15.94 f$ & $3.29 \mathrm{~g}$ & 0.00 & $17.78 \mathrm{~h}$ & $3.80 \mathrm{e}$ & 6.25 & $23.31 \mathrm{f}$ & $4.98 \mathrm{~g}$ & 72.50 \\
\hline 26 & $19.84 \mathrm{e}$ & $3.16 \mathrm{~g}$ & $19.84 \mathrm{e}$ & $3.16 \mathrm{~g}$ & 0.00 & $20.34 \mathrm{~g}$ & $3.50 \mathrm{f}$ & 1.25 & $36.31 \mathrm{e}$ & $4.77 \mathrm{~g}$ & 12.50 \\
\hline 27 & $17.55 \mathrm{f}$ & $2.54 \mathrm{j}$ & $17.55 f$ & $2.54 \mathrm{j}$ & 0.00 & $19.44 \mathrm{~g}$ & $2.92 \mathrm{~h}$ & 0.00 & $47.92 \mathrm{c}$ & $5.09 \mathrm{~g}$ & 0.00 \\
\hline 28 & $20.23 \mathrm{e}$ & $2.67 \mathrm{i}$ & $20.23 \mathrm{e}$ & $2.67 \mathrm{i}$ & 0.00 & $26.87 \mathrm{e}$ & $3.90 \mathrm{e}$ & 2.75 & $43.72 \mathrm{c}$ & $5.41 \mathrm{f}$ & 6.94 \\
\hline 29 & $19.46 \mathrm{e}$ & $3.27 \mathrm{~g}$ & $19.46 \mathrm{e}$ & $3.27 \mathrm{~g}$ & 0.00 & $20.38 \mathrm{~g}$ & $3.73 \mathrm{e}$ & 0.00 & $35.38 \mathrm{e}$ & $4.80 \mathrm{~g}$ & 15.00 \\
\hline 30 & $28.73 c$ & $4.43 \mathrm{c}$ & $28.73 \mathrm{c}$ & $4.43 \mathrm{c}$ & 0.00 & $29.74 d$ & $4.87 \mathrm{c}$ & 0.00 & $42.03 \mathrm{~d}$ & $6.08 \mathrm{e}$ & 9.70 \\
\hline 31 & $31.87 \mathrm{~b}$ & $4.27 c$ & $31.87 \mathrm{~b}$ & $4.27 \mathrm{c}$ & 0.00 & $32.39 c$ & $4.66 c$ & 1.25 & $46.81 \mathrm{c}$ & $5.73 \mathrm{f}$ & 7.50 \\
\hline 32 & $14.66 \mathrm{f}$ & $2.99 \mathrm{~h}$ & $14.66 f$ & $2.99 \mathrm{~h}$ & 0.00 & $16.23 \mathrm{~h}$ & $3.65 \mathrm{e}$ & 12.50 & $21.65 \mathrm{~g}$ & $5.37 \mathrm{f}$ & 81.89 \\
\hline 33 & $31.94 b$ & $4.15 d$ & $31.94 b$ & $4.15 \mathrm{~d}$ & 0.00 & $36.54 b$ & $4.59 c$ & 0.00 & $55.36 \mathrm{~b}$ & $6.84 d$ & 0.00 \\
\hline 34 & $34.45 a$ & $4.02 \mathrm{~d}$ & $34.45 \mathrm{a}$ & $4.02 \mathrm{~d}$ & 0.00 & $38.98 \mathrm{a}$ & $5.08 \mathrm{~b}$ & 0.00 & $64.05 \mathrm{a}$ & $6.72 d$ & 1.25 \\
\hline 35 & $34.19 a$ & $4.37 \mathrm{c}$ & $34.19 \mathrm{a}$ & $4.37 \mathrm{c}$ & 0.00 & $37.88 \mathrm{a}$ & $5.08 \mathrm{~b}$ & 0.00 & $54.77 \mathrm{~b}$ & $7.39 \mathrm{c}$ & 0.00 \\
\hline 36 & $32.83 b$ & $4.24 \mathrm{c}$ & $32.83 b$ & $4.24 \mathrm{c}$ & 0.00 & $33.76 \mathrm{c}$ & $4.86 c$ & 0.00 & $53.72 b$ & $6.73 d$ & 0.00 \\
\hline 37 & $30.97 b$ & $4.25 \mathrm{c}$ & $30.97 b$ & $4.25 c$ & 0.00 & $33.57 \mathrm{c}$ & $5.22 b$ & $1.67 \mathrm{e}$ & $61.41 \mathrm{a}$ & $7.97 \mathrm{~b}$ & 1.67 \\
\hline 38 & $26.52 \mathrm{c}$ & $4.01 d$ & $26.52 \mathrm{c}$ & $4.01 \mathrm{~d}$ & 0.00 & $24.14 \mathrm{e}$ & $4.60 \mathrm{c}$ & 0.00 & $44.33 c$ & $6.07 \mathrm{e}$ & 7.50 \\
\hline 39 & $36.45 a$ & $5.37 \mathrm{a}$ & $36.45 \mathrm{a}$ & $5.37 \mathrm{a}$ & 0.00 & $39.42 \mathrm{a}$ & $6.54 a$ & 0.00 & $66.41 \mathrm{a}$ & $9.56 \mathrm{a}$ & 1.25 \\
\hline 40 & $40.00 \mathrm{a}$ & $4.76 \mathrm{~b}$ & $40.00 \mathrm{a}$ & $4.76 \mathrm{~b}$ & 0.00 & $41.04 \mathrm{a}$ & $4.93 b$ & 0.00 & $44.87 \mathrm{c}$ & $5.53 \mathrm{f}$ & 0.00 \\
\hline 41 & $16.74 f$ & $2.72 \mathrm{i}$ & $16.74 f$ & $2.72 \mathrm{i}$ & 0.00 & $18.93 \mathrm{~g}$ & $3.22 \mathrm{~g}$ & 1.25 & $30.51 \mathrm{f}$ & $4.62 d$ & 20.00 \\
\hline 42 & $29.99 b$ & $4.18 \mathrm{~d}$ & $29.99 b$ & $4.18 \mathrm{~d}$ & 0.00 & $35.32 b$ & $4.80 \mathrm{c}$ & 0.00 & $42.97 \mathrm{~d}$ & $6.09 \mathrm{e}$ & 3.75 \\
\hline
\end{tabular}

Means followed by the same letter in a column belong to the same group by the Scott-Knott clustering algorithm $(\mathrm{P} \leq 0.05)$

usually has low development because, as a response to low temperatures, it reduces its metabolism, retarding its vegetative development, a fact that makes it less vigorous (RODRIGUES et al., 2015; OUSTRIC et al., 2017).
Considering the evaluation period after rootstock transplant, hybrids of Trifoliate orange exhibited similar growth rate and final stem diameter compared to its genitor (Figure 2). Similar 
situation happened to the 'Sunki Tropical' mandarin [Citrus sunki (Hayata) hort. ex Tanaka] and hybrids of the common 'Sunki' mandarin (Citrus sunki). It implies that Trifoliate orange and the 'Sunki' mandarin transmit their own characteristics to their progenies. However, it did not happen to the 'Rangpur' lime and its hybrids, since this tree had final stem diameter of $6.1 \mathrm{~mm}$, while its hybrids showed lower growth rate, with final stem diameter close to $4 \mathrm{~mm}$.

Likewise LCR $x$ CTSW - 009 (citrumelimonia registered by Embrapa, in the NRCMALFS, under the name BRS S Moreira), whose plant mortality was $100 \%$, other rootstocks could not adapt to local climate conditions in the phase of seedling production. Examples are LVK x LCR - 038, whose mortality rate was $90 \%$, and hybrids MXML x LHA - 001 and TSKC x CTSW - 031, with percentages around $80 \%$ (Table 4 ).

Mortality rates of 11 hybrids ranged between $30 \%$ and $80 \%$. Nine out of them had the 'Sunki' mandarin as female parent, a fact that shows that 'Sunki' hybrids tend to have high mortality rates at low temperatures. However, there were exceptions, such as 'Indio', 'Riverside' and 'San Diego' citrandarins, whose mortality rates were about $5 \%$, despite being hybrids of 'Sunki' mandarin. Both hybrids that resulted from crossings that involved the 'Volkamer' lemon did not adapt well, as shown by their high mortality rates.

Eleven hybrids exhibited mortality rates around 5\% (Table 4). Some of them were ready for more precocious grafting: Trifoliate orange, 'Swingle' citrumelo, 'Indio', 'Riverside', 'San Diego', CLEO x TRBN - 245 and CLEO x TRSW - 287 citrandarins, LRF x (LCR x TR) - 005 citrimoniambhiri and the 'Rangpur' lime. Despite their low mortality rate, neither 'Fepagro C - 13' citrange nor HTR - 053 exhibited precocity regarding their grafting readiness.

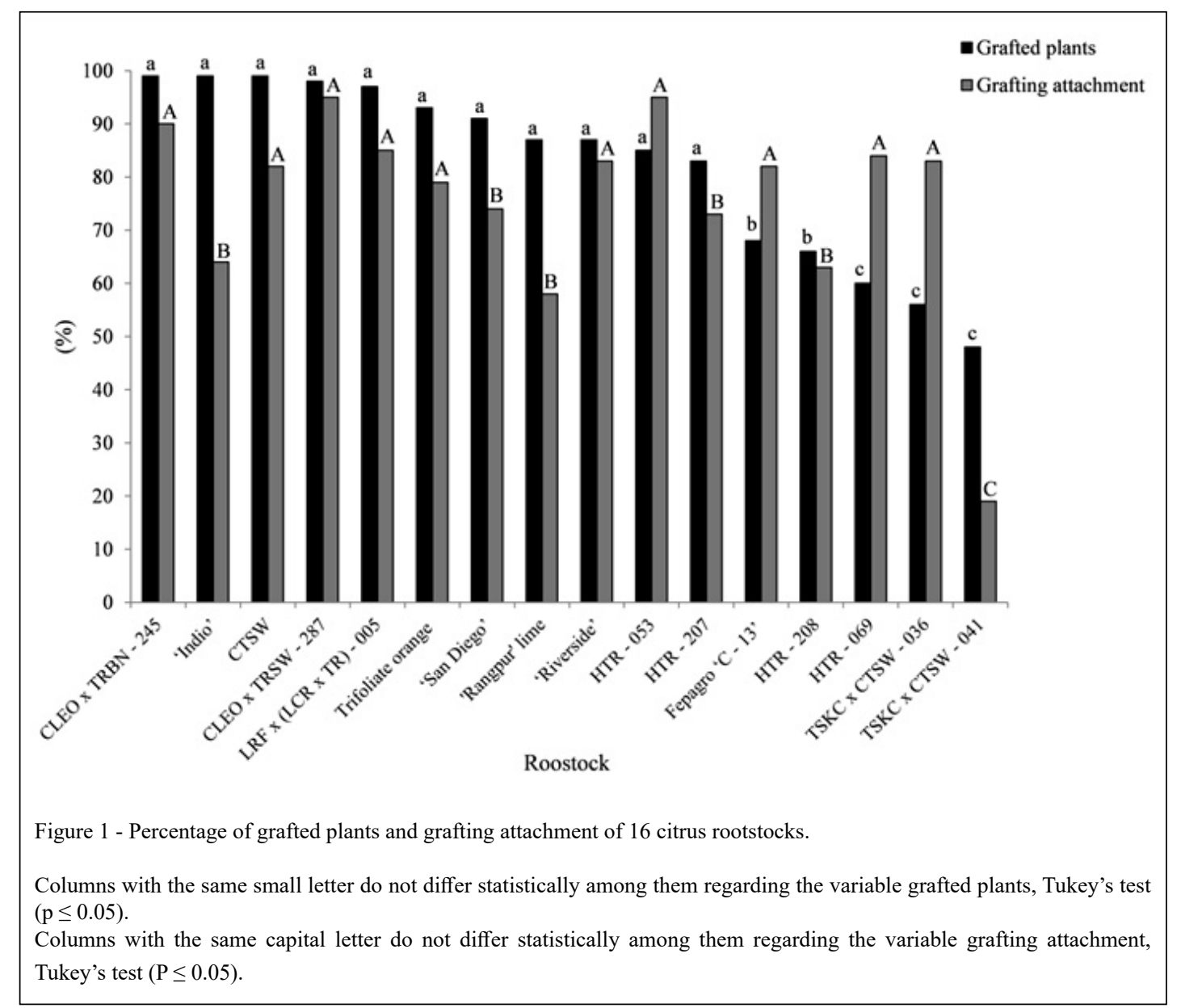

Ciência Rural, v.52, n.1, 2022. 


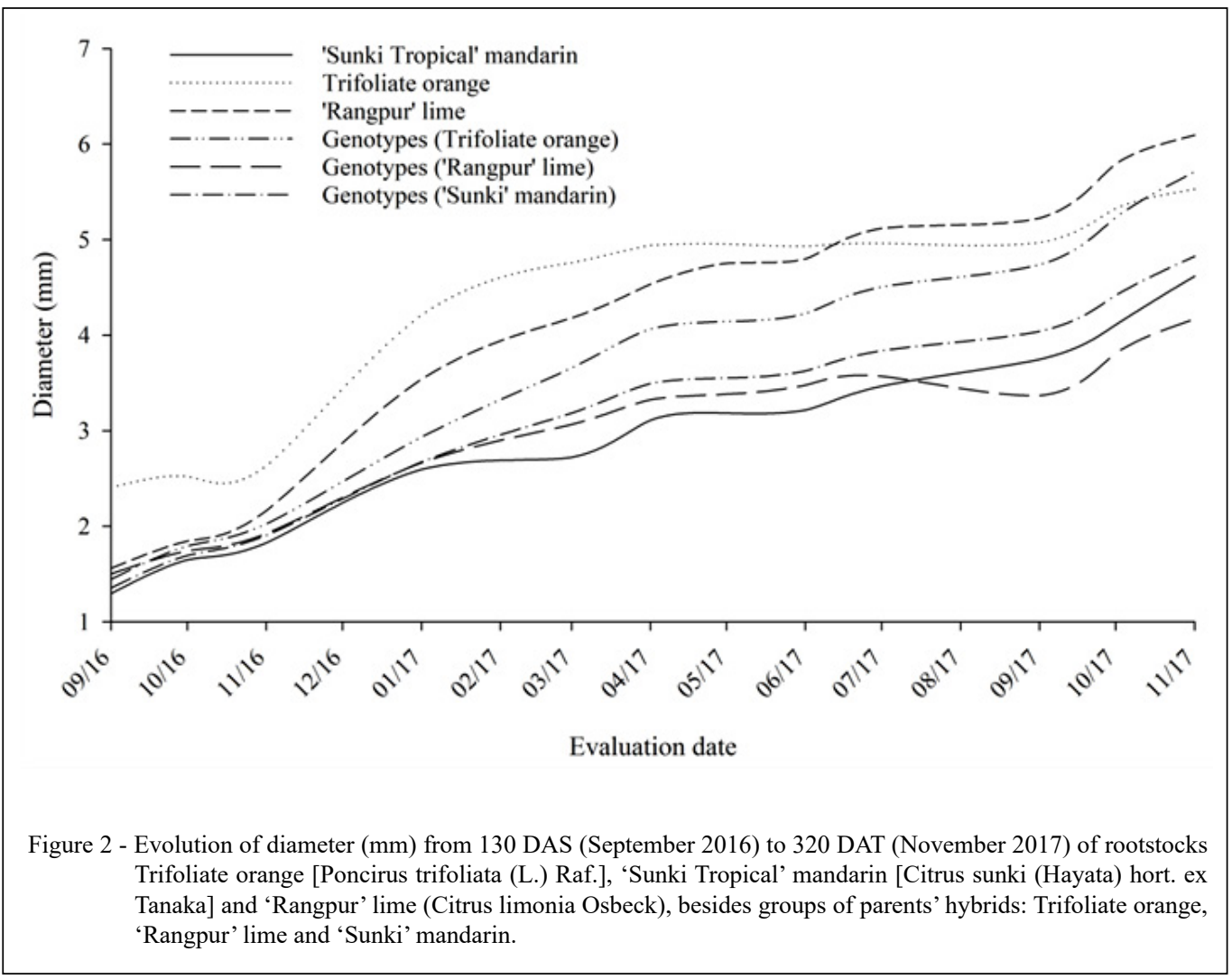

\section{CONCLUSION}

Studies of nursery phases have shown that Trifoliate orange, 'Swingle' citrumelo, 'Indio', 'Riverside', 'San Diego', CLEO x TRBN - 245 and CLEO x TRSW - 287 citrandarins, 'Rangpur' lime, as well as the hybrids LRF $x$ (LCR x TR) - 005 and HTR - 053 have potential to be used as rootstocks in citriculture in RS, Brazil, due to their low mortality and high grafting precocity. Studies of their field adaptability should be carried out so that definite genotypes can be recommended for citriculture in the south of Brazil.

\section{ACNOWLEDGEMENTS}

The present work was carried out with the support of the Coordenação de Aperfeiçoamento de Pessoal de Nível Superior (CAPES) - Financing Code 001.

\section{DECLARATION OF CONFLICT OF INTEREST}

The authors declare no conflict of interest. The founding sponsors had no role in the design of the study; in the collection, analyses, or interpretation of data; in the writing of the manuscript, and in the decision to publish the results.

\section{AUTHORS' CONTRIBUTIONS}

All authors contributed equally for the conception and writing of the manuscript. All authors critically revised the manuscript and approved of the final version.

\section{REFERENCES}

BARON, D. et al. An overview of grafting re-establishment in woody fruit species. Scientia horticulturae, v.243, p.84-91, 2019. Available from: <https:/citarea.cita-aragon.es/citarea/ bitstream/10532/4181/1/2018_271.pdf>. Accessed: May, 05, 2021. doi: $10.1016 /$ j.scienta. 2018.08 .012 .

CARVAlHO, S. A. et al. Advances in citrus propagation in Brazil. Revista Brasileira de Fruticultura, v.41, n.6, 2019. Available from: <http://www.scielo.br/scielo.php?pid=S010029452019000601002\&script $=$ sci arttext\&tlng $=\mathrm{en}>$. Accessed: Jan. 11, 2020. doi: 10.1590/0100-29452019422.

CRUZ, M. A. et al. 'Navelina' sweet orange trees on five rootstocks in Northern Parana state, Brazil. Revista Brasileira de Fruticultura, v.41, n.3, 2019. Available from: <http://www.scielo. $\mathrm{br} / \mathrm{scielo}$.php?script $=$ sci arttext\&pid $=\mathrm{S} 0100-29452019000301001>$. Accessed: Jan. 07, 2020. doi: 10.1590/0100-29452019006. 
FAO. Food and Agriculture Organization of the United Nations statistical database 2018, FAO. Available from: $<\mathrm{http}: / /$ www.fao.org/faostat/es/\#data/QC>. Accessed: Mar. 01, 2020.

GIRARDI, E. A. et al. 'Valencia' sweet orange nursery trees on two rootstocks under different fertilizer managements. Revista Brasileira de Fruticultura, v.32, n.3, p.855-864, 2010. Available from: $\quad<\mathrm{http}: / /$ www.scielo.br/scielo.php?script=sci_arttext\&pid $=$ S0100-29452010000300027> . Accessed: May, 03, 2018. doi: 10.1590/S0100-29452010005000082.

IBGE Instituto Brasileiro de Geografia e Estatística. Levantamento sistemático da produção agrícola: pesquisa mensal de previsão e acompanhamento das safras agrícolas no ano civil. LSPA 2020, IBGE. Available from: <https://sidra.ibge.gov. br/home/lspa/rio-grande-do-sul>. Accessed: Mar. 01, 2020.

MARQUES, L. O. D. et al. Emergence percentage and speed of rootstocks for citriculture in South of Brazil. Journal of Agricultural Science, v.11,n.5, p.49-57,2019. Available from: $<\mathrm{http}: / /$ www.ccsenet.org/journal/index.php/jas/article/view/0/39038>. Accessed: May, 05, 2021. doi: 10.5539/jas.v11n5p49.

MONTEIRO, J. E. B. A. Agrometeorologia dos cultivos: o fator meteorológico na produção agrícola. Brasília: INMET, 2009. 546p. Available from: <https://www.acervodigital.ufpr.br/ bitstream/handle/1884/47918/agrometeorologia_dos_cultivos. pdf? sequence $=1 \&$ isAllowed $=y>$. Accessed: Nov. 17, 2020 .

OUSTRIC, J. et al. Tetraploid Carrizo citrange rootstock (Citrus sinensis Osb. $\times$ Poncirus trifoliata $\mathrm{L}$. Raf.) enhances natural chilling stress tolerance of common clementine (Citrus clementina Hort. ex Tan). Journal of plant physiology, v.214, p.108-115, 2017. Available from: <https://hal.archives-ouvertes.fr/hal-01528069/ document>. Accessed: May, 05, 2021. doi: 10.1016/j. jplph.2017.04.014.

PAROLIN, L. G. et al. Produção de mudas de citros em viveiro protegido, utilizando diferentes combinações de copa e de portaenxerto Cruz das Almas: Embrapa Mandioca e Fruticultura, 2017, 35p. (Boletim de Pesquisa e Desenvolvimento. Documento 84) Available from: $<$ https://www.infoteca.cnptia.embrapa.br/infoteca/ bitstream/doc/1078527/1/BoletimPesquisa84GirardiAinfo84 pdf $>$. Accessed: Sep. 15, 2018.

PASSOS, O. S. et al. Characterization of Poncirus trifoliata hybrids and other citrus rootstocks in the State of Bahia. Revista Brasileira de Fruticultura, v.28, n.3, p.410-413, 2006. Available from: <http://www.scielo.br/scielo.php?pid=s010029452006000300016\&script $=$ sci_arttext $>$. Accessed: Sep. 27, 2018. doi: 10.1590/S0100-29452006000300016.
PEREZ, R. C. et al. Agronomic performance of the acidic Tahiti (Citrus latifolia Tanaka) on different rootstocks. Revista da Jornada de Pós-Graduação e Pesquisa-Congrega Urcamp, v.14, n.1, p.11261135, 2017. Available from: <http://revista.urcamp.tche.br/ index.php/rcjpgp/article/view/870>. Accessed: May, 05, 2021.

PETRY, H. B. et al. Rootstocks influence yield performance of navel orange trees after drastic pruning. Pesquisa agropecuária tropical, v.45, n.4, p.449-455, 2015. Available from: <http://www.scielo.br/scielo. php?pid=S1983-40632015000400449\&script $=$ sci_abstract\&tlng=pt $>$. Accessed: Apr. 20, 2018. doi: 10.1590/1983-40632015v4537005.

RODRIGUES, M. J. S. et al. Fruit characterization and propagation of hybrid citrus rootstocks in protected environment. Revista Brasileira de Fruticultura, v.37, n.2, p.457-470, 2015. Available from: $\quad<$ http://www.scielo.br/scielo.php?pid=S010029452015000200457\&script=sci_arttext $>$. Accessed: Apr. 12, 2018. doi: 10.1590/0100-2945-068/14.

RODRIGUES, M. J. S. et al. Citrus nursery tree production using different scion and rootstock combinations in screen house. Revista Brasileira de Fruticultura, v.38, n.1, p.187-201, 2016. Available from: <http://www.scielo.br/scielo.php?pid=S0100$29452016000100187 \&$ script $=$ sci abstract $\&$ tlng $=p t>$. Accessed: Apr. 30, 2018. doi: 10.1590/0100-2945-284/14.

SARMIENTO, A. I. P. et al. Morphology of fruits and seeds of citrus rootstocks grown in greenhouse condition. Revista U.D.C.A Actualidad \& Divulgación Científica, v.19, n.1, p.17-24, 2016. Available from: <http://www.scielo.org.co/scielo.php?script=sci arttext\&pid=S0123-42262016000100003>. Accessed: Jun. 02, 2018. doi: 10.31910/rudca.v19.n1.2016.106.

SCOTT, A. J.; KNOTT, M. A. Cluster analysis method for grouping means in the analysis of variance. Biometrics, v.30, n.3, p.507-512, 1975 . Available from: $<$ https://www.ime.usp.br/ abe/lista/pdfXz71qDkDx1. pdf $>$. Accessed: Jul. 10, 2018. doi: 10.2307/2529204.

SETIN, D. W. et al. Growth and nutritional status of non-bearing 'Valencia' sweet orange on single and multiple rootstocks of 'Rangpur lime' and 'Swingle' citrumelo. Bragantia, v.68, n.2, p.397-406, 2009. Available from: $<$ https://www.scielo.br/scielo.php?pid=S0006$87052009000200014 \&$ script $=$ sci_arttext\&tlng $=\mathrm{pt}>$. Accessed: May, 05, 2021. doi: 10.1590/S0006-87052009000200014.

TEIXEIRA, P. T. L. Chemical scarification and initial development of citric rootstocks. Revista Brasileira de Fruticultura, v.31, n.3, p.865-871, 2009. Available from: <http://www.scielo. br/scielo.php?pid $=$ S0100-29452009000300033\&script $=$ sci abstract\&tlng=pt $>$. Accessed: Sep. 17, 2018. doi: 10.1590/S010029452009000300033. 